\title{
Chapter 4 \\ Role of State and Non-state Networks in Early-Modern Southeast Asian Trade
}

Atsushi Ota

\subsection{Introduction}

An important characteristic in the history of economic growth of Southeast Asia is that the region had developed brisk trade networks well before the launch of the modern colonial rule during the nineteenth century. The precolonial trade development is a common phenomenon in parts of Europe and West, South, and East Asia, but it is not always the case in other regions including many parts of Africa and South America. Its historical uniqueness therefore deserves scholarly attention, as this can be considered one of the elements related to the recent economic growth of the region.

The precolonial trade in Southeast Asia had a long history, and its patterns were changing throughout different phases of history. Among them "the Age of Commerce" is a famous concept which highlights the trade boom in Southeast Asia from c. 1450 to 1680 (Reid 1993a). After a period of the VOC trade domination (c. 1680-1750), the late eighteenth century had been long considered as the period of decline and fragmentation in Southeast Asia. More recently, however, scholars proposed a concept of the "Chinese century," indicating the trade recovery in a reorganized form in the eighteenth century (Reid 1997; Blussé 1999). The Age of Commerce and Chinese century can be labelled as the early-modern period in Southeast Asia. In spite of the new understanding of the Chinese century, the trade patterns and systems in the early-modern period are still assumed to be very different from those in the following modern colonial period. We tend to consider that modern technology, capital, and political systems dramatically changed Southeast Asian economy and trading patterns during the colonial period, and they were finally subjugated to the West-dominated world economy. As a result, we tend to assume that the

\footnotetext{
A. Ota $(\bowtie)$

Keio University, Minato-Ku, Tokyo, Japan

e-mail: ota@econ.keio.ac.jp

K. Otsuka and K. Sugihara (eds.), Paths to the Emerging State in Asia and Africa, Emerging-Economy State and International Policy Studies, https://doi.org/10.1007/978-981-13-3131-2_4
} 
modern colonial economic systems formed large parts of the basis of Southeast Asian economy today, disconnected from its early-modern past.

Against these assumptions, I argue in this chapter that the elements that characterizes in Southeast Asian trade were created and developed in the early-modern period, especially after the Age of Commerce. I rename the Chinese century as the Age of China-oriented trade, because what characterizes this period was not only Chinese trade and migration, as was often assumed, but the fundamental change in the state-commerce relationship, in which Southeast Asian actors played a crucial role, as a result of the shift in the nature of trade. I also argue that the China-oriented trade remained important until around 1870, buttressing the growing long-distance trade with Europe during the so-called early colonial period (c. 1820-1870), and beyond. Special focus is given not only to state politics on trade, but also to the role of non-state networks, in which crucial actors were traders as well as commercialmilitary groups, which are sometimes also called pirates. Because of my specialty, the discussion of this chapter concentrates on insular Southeast Asia.

In this chapter state refers to any autonomous political body that claims to exercise supreme authority over a certain territory and more strongly over people living there. This vague definition covers a wide range of political bodies from an early-modern petit statelet to a colonial state with rigid legal and taxation structure. Nevertheless such a wide coverage will enable us to explore various elements in politico-commerce relationship in a single framework, and to discuss their diversity and development effectively.

\subsection{Age of Commerce}

\subsubsection{The Rise of the Trade and Its Basic Pattern}

"The Age of Commerce" is a concept raised by the historian Anthony Reid, to refer to the trade boom from c. 1450 to 1680. In search of precious Southeast Asian products such as spices (e.g. nutmeg, mace, and clove), wood (sandalwood and aloeswood etc.), pepper, and various kinds of forest products, traders from West, South, and East Asia, and later those from Europe visited a number of trading ports in Southeast Asia. ${ }^{1}$ These foreign traders brought their items either from their places of origin or from the transit ports that they passed by on the way. The most significant among them in Southeast Asian trade were Indian textiles, Japanese silver, and Chinese manufactured products such as porcelain and metal works.

According to Reid, the important elements to trigger the boom are (1) the incorporation of Southeast Asian states into the China-centered tributary system, (2) the arrival of Muslim traders from West Asia and Northwest India, and (3) the inflow of American and Japanese silver. First, in 1402 Yongle Emperor of the Ming dynasty

\footnotetext{
${ }^{1}$ For more information of the external elements that affected Southeast Asian trade, such as Chinese, Indian, and European traders, see Chap. 3 of this volume.
} 
called for Asian rulers of independent states to participate in the Chinese tributary system, to expand his influence throughout maritime Asia. Under this system, southern "barbarian" rulers were requested to send their tributary missions to Nanjing, the Ming capital at that time, thereby accepting the authority of the Ming Emperor. In return they were granted the official permission to conduct trade with China, a lucrative commercial opportunity amidst the strict trade ban of the Ming dynasty. In addition, as the Ming Emperor strictly forbade the rulers under the tributary system from fighting with each other, the system also guaranteed peace among them.

Second, under the rule of the powerful empires such as the Abbasid Caliphate (750-1258, 1261-1517) and the Safavid dynasty (1501-1736), the activities of Muslim traders like the Arabs, Persians, and Gujaratis expanded to Southeast Asia, in search of precious tropical products. Third, the Japanese and American silver, the production of which expanded in the sixteenth century, was brought into Southeast Asia in large quantities, which facilitated the transactions of Southeast Asian products.

Southeast Asia was attractive for foreign traders, first of all because the region produced precious products available only in very limited areas, such as nutmeg and mace grown only in Banda Islands and clove in Ternate and Tidore islands. On the other hand, the demand for these Southeast Asian products were very strong in Asia and Europe because they were not only used for flavoring but also for medical purposes.

The basic pattern of trade in the Age of Commerce was the exchange between precious natural products from Southeast Asia (spices and woods etc.) and foreign manufactured products (especially Indian textiles and Chinese porcelain). In terms of traders, Southeast Asians were most prominent in the local trade (trade between producing areas and transit ports in Southeast Asia), while the regional trade (trade between transit ports in Southeast Asia) was conducted by Chinese, Indian and Southeast Asian traders. In long-distance trade (trade between Southeast Asia and other parts of the world) Chinese, Indian, and European traders were most prominent in the respective routes from their places of origin. Main consumers of Southeast Asian products in this period were a small number of rich and powerful people, such as members of the royal families, nobles, and privileged merchants, and items that they demanded were small-volume, high-value products (Reid 1993a). This basic trade pattern significantly changed in the mid-eighteenth century, as I discuss later.

\subsubsection{Southeast Asian Characteristics}

Considering the fact that a similar trade boom did not take place in many other parts of the world, such as Africa and South America, it is worth asking why the trade boom happened particularly in Southeast Asia. The existence of the products available only in this region, and its location between the great civilizations of India and China are frequently mentioned reasons, but they do not fully explain the trade boom. Outside traders would not have found these products, if there were not for local knowledge 
of the usefulness of the products, and for the local trade, which brought the products to the attention of outside traders. Local people created the network to bring the valuable products from the producing areas to nearby markets and transit ports. It was the existence of active local trade that gave foreign traders access to the precious products in Southeast Asia.

Why were the locals able to develop local trade in Southeast Asia? In fact, Southeast Asians had a very long history of maritime activities. Austronesians migrated from Taiwan to most areas of maritime Southeast Asia before 1500 B.C., fully making use of their excellent knowledge of shipbuilding and maritime navigation. Local trade in Southeast Asia must have been active before the first century B.C., as is known in Chinese sources, perhaps with the knowledge of monsoon winds. Indian traders were regularly dealing in spices grown only in small islands in East Indonesia in the first century A.D., according to a Greek text, perhaps because Southeast Asian traders brought them to transit ports. In addition, environmental elements were also favorable for trade. The seas among numerous islands are relatively calm, and a number of rivers were navigable. Deep forests provided ample wood materials for shipbuilding. The combination of these trade-friendly environments and the ancient knowledge of shipbuilding, long-distance navigation, and monsoon winds was unique in Southeast Asia, and this became the basis for the region to enjoy a trade boom in the early-modern era, in addition to the precious natural products grown or collected only in this region.

\subsubsection{State Politics and Its Impact on Society}

In order for foreign traders to obtain popular Southeast Asian products, it was necessary to find convenient transit ports, as the producing regions of these products were often very far from the main routes of maritime trade between China and India. They emerged in nodal points of traffic, such as the coast of the Gulf of Thailand, both sides of the Straits of Malacca, and the north coast of Java, and provided opportunities for foreign traders to exchange their goods they brought with them with the products from remote areas of Southeast Asia (Reid 1993a).

The growth of the transit ports soon led to the emergence of a particular type of state in Southeast Asia in the Age of Commerce-port state. ${ }^{2}$ Different from the older agriculture-oriented states such as Angkor and Majapahit, ${ }^{3}$ the rulers of the port states relied their wealth and power on maritime trade. Not only did they obtain large parts of income from the customs and trade-related taxes from local and foreign traders, but also they organized trade fleets by themselves. The typical examples

\footnotetext{
${ }^{2}$ This type of state has often been called port polity, probably in order to include small statelets typical in Southeast Asia in discussion. However, for the purpose of simplifying discussion, I use the term port state to mean any scale of political body, which relies its economic, political, and ideological base on ports under its influence.

${ }^{3}$ The Srivijaya Kingdom was also a sort of alliance of port states. See Chap. 3, Sect. 3.2.
} 
of port states include Ayutthaya, Pasai, Aceh, Perak, Palembang, Banten, Demak, Gresik, Makassar, and Brunei, although they rose and fell in different periods during the Age of Commerce.

The politics of port states focused on the promotion of trade. In order to protect the ships laden with precious cargos from the attacks of pirates and gangsters, the rulers built walls and bulwarks, and organized naval fleets. As traders naturally preferred well protected ports, effective protection promised rulers more income from trading ships.

In order to effectively promote trade, however, military power was not enough. First, rulers attempted to make use of the knowledge and skills of foreigners, to attract their compatriot traders. The rulers often created special quarters for particular ethnic groups to reside in or immediately outside their capitals. These foreign communities actively conducted trade within and beyond the host state, and the rulers often appointed the representatives of each community in an important position such as the harbor master (shahbandar). As a result, the multi-ethnic formation of major port cities became the tradition in Southeast Asia, far before the colonial rule. Second, rulers attempted to establish peace and order in their ports and nearby waters, by issuing rules and regulations in their state. The Malay law codes, a corpus of rules and regulations first promulgated by the sultan of Malacca, was such an example. Many of the rules and regulations were concerned with smooth operation of trade and commercial transactions. Third, some rulers attempted to attract Muslim traders, by creating places for worship, such as mosques. In insular Southeast Asia, some rulers also chose to convert themselves to Islam.

The conversion to Islam and the promulgation of law codes were also elaborated strategies on the part of rulers for their legitimacy. For example, in the north coast of Java, rulers of the newly emerging port states like Demak adopted Islam as a new source of legitimacy, in order to counter the land-based Hindu Kingdom of Majapahit. Being the propagator of Islam in their states also meant that the ruler became a mediator between the local secular world and the (imagined) holy outside world. This must have attracted the awe and admiration from local people. Likewise, the rulers who established law codes were respected as the protector of peace and order. The wide application of Malay law codes and the popular use of the Malay language in commerce enhanced the position of the sultan of Malacca as the center of the Malay World.

The state was also involved in trade. The rulers monopolized not only the trade of important export items such as nutmeg and pepper, but also their production. For example, the rulers of Banda and Banten placed strict state control on the production of nutmeg and pepper respectively, and forced the cultivators to sell the products only to the rulers.

Through these sorts of politics, states played a prominent role in the promotion of trade. This is a most important characteristic in the Age of Commerce. State rulers protected their ports militarily, and they organized the systems for smooth transactions by creating amicable environments for traders. As these features were not necessarily the case after the eighteenth century, it is worth considering why it took place in the Age of Commerce. First, it should be noted that important export 
items in the Age of Commerce, such as nutmeg, mace, clove, pepper, and sandalwood were produced only in very limited areas, and therefore state control of the production and trade of these items was relatively easy. The ships laden with these high-value items must have tended to anchor in ports under the powerful ruler, in the expectation of effective protection. As ships tended to concentrate on a small number of influential ports, powerful port states had a chance for further prosperity. Second, these powerful states tended to monopolize the import of weapons. When state rulers were powerful enough to dominate trade, other influential members, either within or outside the royal family, had less chances of obtaining weapons from foreign traders. From these reasons, states were in a position to take an initiative in local and regional trade during the Age of Commerce.

What sort of impact did the trade boom during the Age of Commerce have on society in the history of Southeast Asia? First, the development of regional trade strengthened common material culture in Southeast Asia, such as the custom of betel chewing, flavoring with fermented fish, and the use of cotton for clothing. Second, as local trade developed, some port cities and cash-crop producing areas abandoned food production, relying on the supply from food-producing areas. The division of labor was considered to be a condition of economic development, and this took place particularly in the Age of Commerce in Southeast Asia. Seen from a different angle, however, the intensified division of labor also meant that some areas lost economic self-sustenance. Some port cities and cash-crop producing areas had to depend on trade to obtain food and other necessities. Food-producing regions also increased the production of food such as rice, by importing necessities such as textiles. This is how certain areas of Southeast Asia became a trade-dependent society during the Age of Commerce. This would explain the continuation of local trade in the following centuries.

Although influential merchant elites emerged in several trade-oriented states, capital did not accumulate among them. As Reid explained, this can be attributed to the strong interests of state rulers in commerce. Because they enthusiastically attempted to benefit from trade and production control, they were equally enthusiastic to prevent powerful merchants from becoming so rich and influential as to threaten their wealth and power (Reid 1993a). Capital accumulation did not take place, in the way that it did to prepare the birth of capitalism in Europe around the same time.

Reid explained that the Age of Commerce ended around 1680, when the Dutch East India Company (Verenigde Oostindisch Compagnie or VOC) had created their trade network centered on its Asian headquarters in Batavia. In return for military supports in internal conflicts in local states, the VOC forced the rulers to conclude treaties, which allowed monopoly rights for the VOC to trade their major export items. These items were first sent to Batavia, from which they were re-exported to many places in Asia and Europe. Finally, defeating its major rivals, Macassar and Banten by the 1680s, the VOC reorganized the trade pattern from the decentralized open system in the Age of Commerce to their centralized monopolistic system. In the states under their influence, the Dutch often placed the production of important cash crops under control. This usually resulted in production decline in many places because cultivators disliked the enforcement and unfavorable prices that the VOC 
had set. Some influential states such as Mataram and Aceh, losing their interest in external trade, concentrated more on the agricultural production in the inland. According to Reid, regional and local trade in Southeast Asia thus fell into decline in the late seventeenth century (Reid 1993a).

\subsection{Age of China-Oriented Trade}

\subsubsection{Rise of a New Trade Pattern}

Several years later after the publication of The Age of Commerce in Southeast Asia, however, Reid revised his argument of the trade decline after the late seventeenth century. Now he has emphasized the trade recovery in the mid-eighteenth century, which he has called the "Chinese century." He argues that Sino-Southeast Asian trade and the Chinese migration to Southeast Asia developed from the mid eighteenth century, because of the new Chinese interest in Southeast Asian products (Reid 1997). My own research largely agrees with Reid's view, while there are some differences in the following points. First, the term "Chinese century" gives an impression that the Chinese played a far more important role than others in the story of trade recovery. In fact Southeast Asians such as Bugis, Iranun, and Malays also took a crucial role. Second, the increase of trade in this period did not only mean the participation of new players and new trade items. It should be emphasized that it brought a total reorganization of trade patterns and state formation in Southeast Asia. Third, the "Chinese century" did not end with the fall of independent states during the nineteenth century, as Reid seems to imply, but it survived the colonial trade pattern. I call the new trade pattern that emerged in mid-eighteenth century Southeast Asia the Chinaoriented trade, and I identify the period of this trade pattern as roughly from c. 1750 to c. 1870. In this section I will explain the development and characteristics of this trade pattern, and the typical local politics towards the trade.

It was the economic growth in China that triggered the boom of Sino-Southeast Asian trade, as Reid has explained. First, in order to meet the food demand caused by the rapid population growth, the Qing government started to import rice from Saigon and Ayutthaya by loosening its maritime ban. Second, the expanding middle strata of the society in economically advanced areas, such as the South China coast, Beijing, and the middle- and downstream Yangzi basin, witnessed growing demand on exotic tropical products from Southeast Asia, such as marine products like sea cucumber and shark's fin, forest products like rattan and resin, and others such as birds' nests, pepper, and tin. Southeast Asian traders collected these products in numerous places in insular Southeast Asia, and brought them to regional trade hubs, from which Chinese traders brought them back to South China coast. This is how a new trade pattern, dealing with China-bound Southeast Asian natural products, emerged in the mid eighteenth century. 
The demands on the abovementioned types of Southeast Asian products in China seem to be related to the "middle-class luxury" (Pomerantz 2000) among those who enjoyed growing purchasing power under the strong economy during the long reign of Qianlong Emperor (1735-99). It was around this period that dining places increased in large cities, and the royal cuisine spread to the wider circle of society. Those who newly obtained economic power wanted to have higher self-esteem and social recognition through the consumption of items that were consumed in the upper circle of society, among them imported items. Exotic edible items from Southeast Asia, such as sea cucumber, shark's fin, and birds' nests, were typical items for this type of consumption. These items were indeed rare and expensive, but they were still much more easily available than clove and sandalwood during the Age of Commerce. Other Southeast Asian items were also related to mass consumption. Tin was used for tea container and also for fake paper notes burnt in rituals, while rattan was processed into various kinds of furniture. These were new types of mass consumption items, which were still considered luxurious but widely used today across the wide spectrum of society.

\subsubsection{Shifting Trade Hegemony}

The Chinese traders headed for Southeast Asia in large numbers, especially after the lifting of maritime ban in 1727, and they tended to call at transit ports outside the Dutch sphere of influence. This is partly because they disliked the regulations imposed in Dutch ports such as Batavia and Malacca, and also because the Dutch were not interested in the China-bound items. Riau (South of Singapore), Saigon, Jolo (Sulu islands in the Southwest Philippines), and Spanish Manila were typical ports from which China-bound Southeast Asian items could be obtained.

Stimulated by the growing Chinese demand in Southeast Asian products, British traders joined this new pattern of trade. After the opening of Canton (Guangzhou) to Western traders in 1757, British, Dutch, and other European traders imported large amounts of tea from China to Northwestern Europe such as Britain, France, and the Netherlands. Tea party became an important opportunity for socialization among upper-class ladies in these states, and the custom of tea party expanded from the Netherlands to other countries, and also to wider strata of society. This is how this growing demand on China tea was also related to the emerging mass consumption culture in Northwest Europe. Europeans, however, did not have attractive items from home for the China market. In order to save precious silver drained in the purchase of tea, the English East India Company (EIC) and British country traders (those who conducted trade in Asia with the official permission from the government of British India) attempted to bring Asian products demanded in China. Large parts of their items brought to Guangzhou were Indian cotton and opium, but not small amounts of Southeast Asian tin, pepper, and other items were also imported (Ota 2006). In order to obtain these Southeast Asian items, British country traders also visited independent ports outside the Dutch sphere of influence, for the same reasons as those of Chinese 
traders. To Southeast Asia, British country traders mostly brought Indian textiles and opium, and Western weapons. Because these items had strong demand among local rulers, country traders soon became a main player in Southeast Asian trade. Because the state-chartered EIC had difficulties to deal with these clandestine items, it was mainly private country traders who dealt in them.

The visit of an increasing number of Chinese junks and British country traders to non-Dutch ports transformed the trade pattern in maritime Southeast Asia. Not only Chinese and British but also local traders gathered in these ports for the business with foreign traders after the mid-eighteenth century. Receiving these traders, independent ports such as Riau and Jolo, the capitals respectively of the Johor and the Sulu Kingdoms, emerged as important trade hubs. This development inevitably undermined the position of the VOC.

Although the abovementioned China-bound items were out of Dutch interest, the rise of these ports was a crucial threat for the VOC. For example, Jambi and Palembang started to export their tin and pepper to Riau, not to Batavia, in spite of the fact that these items were supposed to be placed under the VOC monopoly. Local traders preferred Riau because of the better conditions offered by Chinese and other traders. The rise of independent ports and their growing trade seriously undermined the VOC trade control.

From the 1780s Johor Sultanate and the VOC fiercely competed over the trade hegemony in Malay waters. The tension culminated in the military clash in 1784, and it resulted in the VOC conquest of Riau. Scholars had considered that the fall of Riau brought confusion and trade decline in Malay waters because it resulted in the absence of a strong state power to control trade before the British establishment of Singapore in 1819. However, I have discussed elsewhere that the Dutch conquest of Riau in the 1780 s did not mean the end of active trading in the surrounding waters. First, although Riau indeed lost the function of a trade hub after the Dutch conquest, several other ports, such as Sukadana and Pontianak, soon emerged as alternatives. Chinese, Southeast Asian, and British traders visited these ports, in order to obtain China-bound Southeast Asian products (Ota 2010).

Second, although there were a number of records of "pirate" attacks in the Straits of Malacca after the fall of Riau, this did not necessarily mean trade decline. For example, after the end of the 1780s Dutch pepper trade was indeed heavily disturbed by so-called pirates, consisting of Bugis, Malay, Iranun, and other Southeast Asians. They frequently made assaults on passing cargo ships and on the inland pepper-producing areas in Lampung in South Sumatra, the largest pepper provider in Southeast Asia at that time. As Lampung pepper was supposed to be sold exclusively to the VOC on the basis of a treaty with the sultan, the "pirate" attacks were a serious problem for the VOC. For VOC officials, these Asian attackers were no doubt pirates. However, the pepper deprived by these groups was in fact circulated on a commercial domain. The attackers usually sold their pepper, a part of which they sometimes purchased in the producing regions, to Chinese and British traders waiting in meeting points outside Lampung. In a VOC record, the pepper deprived by non-Dutch actors around Lampung amounted to 3,400 picols or about $36 \%$ of the VOC pepper trade in Batavia in a year (Ota 2006). Considering the usual activities of 
Chinese and British traders at this time, it is very likely that the deprived Lampung pepper was finally brought to China. In this way, so-called pirates played a role to bring the pepper placed under the Dutch monopoly to the China market, to meet the strong demand there. It therefore seems reasonable to call them armed traders or commercial-military groups. Because of their contribution trade actively continued in the Malay waters after the fall of Riau.

\subsubsection{New Migration Patterns}

In addition to the growth of the trade of China-bound products, another remarkable feature in the Age of China-oriented trade was active migration of various groups of people. As Reid and other scholars have discussed, Chinese migration was most prominent among them. Local rulers of thinly populated tin-mining regions in Malay Peninsula and Bangka Island agreed with Chinese traders to introduce Chinese labor and skills, in order to increase the production. Gold mines in West Kalimantan attracted waves of Chinese laborers. Chinese migrants also opened pepper and gambir gardens in Terengganu, Brunei, and Riau, to meet the demand in China. The products of these mines and gardens were almost exclusively exported to China by Chinese traders. These migrants were mostly from Fujian and Guangdong Provinces in South China. Under the population pressure during the eighteenth century, a number of Hokkien, Cantonese, Hakka, and Teochew, many of whom had experiences in commercial agriculture and mining in their hometown, headed for Southeast Asia (Reid 1997).

The Chinese migrants in this period often created their communities in inland areas around mines and gardens, different from those in the previous centuries, when Chinese communities usually concentrated in the coastal areas. The transit ports in the coastal areas, such as Malacca, Riau, and Pontianak, and later Singapore and Kuala Lumpur, played an important role in the trade with upstream migrant communities, to export the products from Chinese gardens or mines, and to import necessities for the Chinese migrant communities. Although it is generally understood that the emergence of this type of Chinese migration was a phenomenon in the high colonial period, in fact it started in the late eighteenth century, though on a smaller scale and without any colonial settings.

It should be also noted that not only Chinese but also Southeast Asians actively migrated in the Indonesian and Philippine Archipelagos, and they played a significant role in the transformation of the trade pattern. One of the prominent migrant groups was the Bugis, originally from around Makassar in South Sulawesi, known for their excellent knowledge and skills in maritime navigation, commerce, and battle. During and after the Makassar War in 1660-66, with which the VOC finally conquered Makassar, the Bugis took refuge to various parts of the Indonesian Archipelago, and they created their communities in the coastal areas. As the China-oriented trade developed, the Bugis played an important role in bringing marine and forest products to transit ports, utilizing their extensive network throughout insular Southeast Asia. 
Another prominent migrant group, the Iranun, was originally from Magindanao in South Philippines, and formed an influential group in the Sulu Kingdom. As its capital Jolo grew with the expanding China-oriented trade, the activities of the Iranun also expanded. They collected marine products, and more notoriously abducted people to use them as marine-product collectors, rowers of their ships, and slaves in their communities. Malays and some other groups also actively migrated within the Indonesian Archipelago, conducting the trade of marine and forest products. It was also very common that different ethnic groups acted together under an outstanding leader (Ota 2014).

These Southeast Asian migrants were routinely involved in local and regional trade in a heavy-handed way, using their networks and violence, to obtain particular items. It was this type of migrant groups that formed the abovementioned commercialmilitary groups.

\subsubsection{Basic Trade Pattern}

Although Asian traders regained the leading role in the trade in this period, the new trade pattern was different in many respects from that in the Age of Commerce. The composition of major Southeast Asian exports changed from high-value smallvolume natural products to the bulkier mass-consumption items, such as marine and forest products, tin, pepper, and birds' nests.

In return, Southeast Asia imported Indian textiles via Indian traders, opium and Western weapons via British traders, and Chinese sundry items such as paper and pottery from Chinese traders. Although Indian textile trade had shrunk towards the end of the Age of Commerce, Southeast Asians seem to have restarted its import. Opium consumption in the eighteenth century seems to have mostly concentrated on Chinese migrant workers. This type of opium consumption was well known in the high colonial period, but it surely started in some Chinese communities such as sugar gardens outside Batavia in the Age of the China-oriented trade (Ota 2006). These things seem to indicate that Southeast Asians had a significant purchasing power, most probably through the export of China-bound items, which Chinese traders bought with silver. The Outer Islands (the territory of Dutch East Indies apart from Java and Madura) had a sizable export surplus in the nineteenth century, as shown in the following section, largely as a result of the growing export of natural products to China. Probably there were similar developments in the eighteenth century.

In terms of traders, Chinese junk traders and British country traders took part of the trade between South China coast and Southeast Asian ports. Apart from British traders, Europeans did not play an important role. British traders cooperated local and Chinese traders and commercial-military groups to trade (often clandestine) items in defiance of the VOC monopoly. For local and regional trade, Southeast Asian commercial-military groups played a crucial role in bringing natural products from the producing areas to local transit ports. 
The shift in major Southeast Asian exports from small-volume high-value items to bulky mass-consumption items exerted powerful impacts on the producing regions. Different from the major exports in the previous centuries such as precious spices and wood, marine and forest products were collected spanning much larger areas. This means that the state control of the collection and trade of export products, as attempted in the Age of Commerce, became much less effective and therefore it was hardly conducted on the items such as rattan and shark's fin. ${ }^{4}$ Without hardly any state monopoly, a much larger number of people came to be involved in commercial activities across wider areas. It seems very likely that local people became much more accustomed to commercial transactions, and became increasingly market-oriented through the collection of export items.

\subsubsection{Commercial-Military Groups and States}

The trade of forest and marine products made the role of the commercial-military groups more important. The producing and collecting areas of those products were usually far from state centers and state protection. Traders therefore had to arm themselves to defend their cargos and ships against attackers on seas and rivers. In order to obtain human captives to sell as slaves, military power was essential, while heavy armament was also advantageous to get an upper hand over commercial rivals. Maritime migrants such as the Bugis, Iranun, and Malay therefore tended to heavily arm themselves and organized commercial-military groups. These non-state groups obtained weapons, which were much more easily available than in the previous centuries. As mentioned earlier, British country traders brought Western weapons including firearms. Spanish and Dutch records tell that a number of commercialmilitary groups bought weapons from British traders in Sulu and the Malay waters (Warren 1981; Ota 2006).

The rise of commercial-military groups also had an impact on the state formation. States no longer played so prominent a role in the control of trade as they did in the Age of Commerce. States in this period often attempted to promote trade by establishing a strong connection with commercial-military groups. These groups were useful for states not only to obtain China-bound products, but also to gain military support for conflicts with their rivals. In return, states provided privileges such as a high official position and tax exemption. For example, Johor Kingdom, which had received waves of Bugis migrants after the Macassar War, gave influential Bugis families a hereditary position of Raja Muda (viceroy). The Sultan of Sukadana provided migrant groups with a place to settle down and tax exemptions, and granted their leader with a high official position (Trocki 1979; Ota 2010).

\footnotetext{
${ }^{4}$ There are records of state priority in the purchase of birds' nests in West Kalimantan, but the same records also indicate that the attempt was not very successful. The local chiefs of the producing region sold only a small part of the products to the state ruler, because of the weak state control (Ota 2010).
} 
Some states were indeed established by the leaders of commercial-military groups. The founder of Mempawa in West Kalimantan was a legendary prince who took selfrefuge after the Makassar War (Andaya 1995). The founder of Pontianak had been the leader of a notorious commercial-military group who had assaulted the south and east coasts of Kalimantan. After years of roaming, he went with his 200 followers to West Kalimantan, to establish the new state of Pontianak. His group consisted of a mixed group of people who were attracted to his charisma in his leadership in the successful trade and assaults (Ota 2010). This type of leadership to achieve economic success through commerce and violence formed a stronger basis of the legitimacy of the ruler in this period, than becoming a religious mediator or a promulgator of law codes, as was the case in the Age of Commerce.

States in the Age of the China-oriented trade were generally smaller, and they played a less prominent role to sustain the trade network than those in the Age of Commerce. It was rather commercial-military groups that played a larger role in the trade in insular Southeast Asia. Considering their role discussed above, it is possible to argue that commercial-military groups played a significant role in the continuation of local and regional trade, regardless of the rise and fall of states. For example, as I explained before, after the VOC conquest of Riau in 1784, trade continued using different hubs such as Sukadana and Pontianak. Lampung pepper was exported through commercial-military groups to China toward the end of the eighteenth century. These things mean that commercial-military groups took an initiative to continue trade under weak state control.

There is virtually no trace of capital accumulation among the commercial-military groups in this period. They were oriented not only to increase their economic wealth but also to enhance their military and political power, so that they did not always use their economic gain to accumulate capital nor to invest it in a new enterprise. They had to use large parts of their wealth for their armament and for military/political conflicts. Under the weak state authority there were neither effective state protection of safe commercial activities nor development of a legal framework to guarantee private properties. Local producers and collectors of China-oriented exports had a chance to get involved in small-scale commercial activities, but the economic environments were not so friendly for larger-scale entrepreneurs to increase their wealth.

\subsection{Transition to Colonial Trade, c. 1830-1870}

\subsubsection{End of the Chinese Century?}

In his edited volume discussing the "Chinese century," Anthony Reid and other contributors explored the development of local economy, state diplomacy, and commercial politics in the independent states in Asia. Many of them ended their discussions with the fall of the independent states during the colonial period. This gives an impression that the trade patterns of the Chinese century ended with the 
establishment of colonial rule, and they were taken over by the colonial trade. Indeed the new trade pattern developed soon after the establishment of British Singapore in 1819, and the regional trade of Southeast Asia was increasingly channeled to the one centered on Singapore throughout the nineteenth century, as Kobayashi discusses in the following chapter in this volume.

The rapid growth of Singapore, however, did not mean the disappearance of the China-oriented trade. On the contrary, the China-oriented trade steadily grew during the colonial period, at almost the same pace of the growing colonial trade bound for Western countries (Fig. 4.3). How was it possible?

\subsubsection{Trade in the Outer Islands}

I take the ports in the Outer Islands under the Dutch influence (hereafter the Dutch Outer Islands ports) for the examination of this question, as we have a standardized set of statistic records created by Dutch officials in a number of ports from Sumatra to Maluku. These ports include only those in which the Dutch authorities collected taxes, and therefore these sources do not include the trade of powerful independent states in Aceh and Bali, for example. ${ }^{5}$ Figure 4.1 indicates the major exports from the Dutch Outer Islands ports from 1846 to 1869. In this figure, I categorize Southeast Asian export products into three groups, on the basis of producer, collector, or investor, as follows: "Local products" mean those collected or produced by local people, such as forest and marine products bound for China. "Chinese products" are mostly pepper, gambir, and tin produced by migrant Chinese workers and exported to China. "Colonial products" are those produced with Western investments and exported to Western countries for industrial use or for mass consumption, such as rubber, tobacco, and coffee. Until the 1850 s tin and gambir were exported mainly to China and partly to other parts of Southeast Asia for traditional use (tin as explained before, and gambir as an ingredient of betel chewing), but in the 1860s a tin mine in Belitung and gambir gardens in Riau were reorganized on a much larger scale with Western investments for exports to Europe and the US for industrial use (tin for canned food,

\footnotetext{
${ }^{5}$ The interpretation of this set of statistics involves particular difficulties, which derives from the different degree of accuracy in the information collected from different places. For example, the volume of "the import from the Outer Islands to Java" collected in the Outer Islands is sometimes about three times larger than "the export from the Outer Islands to Java" collected in Java in 1846, although they refer to exactly the same trade. This resulted from the fact that the ability for the authorities to capture the trade in the ports in the Outer Islands was weaker than that in Java. In the Outer Islands, considerable number of traders seem to have evaded trade taxes by using small ports outside the Dutch control. Although this type of confirmation is possible only between Java and the Outer Islands as statistics are compiled in the same format, the same tendency probably took place in other places. We have to take into account this inaccuracy in the trade volume, but the trade trend, such as the distributions of exports to different destinations and those of different origins of import, is still reliable and deserves analysis. The ability of the port authorities to capture trade later improved, and by 1869 the volume of the trade measured in Java was only 1.2 times larger than that of the same trade measured in the Outer Islands (Ota 2013).
} 


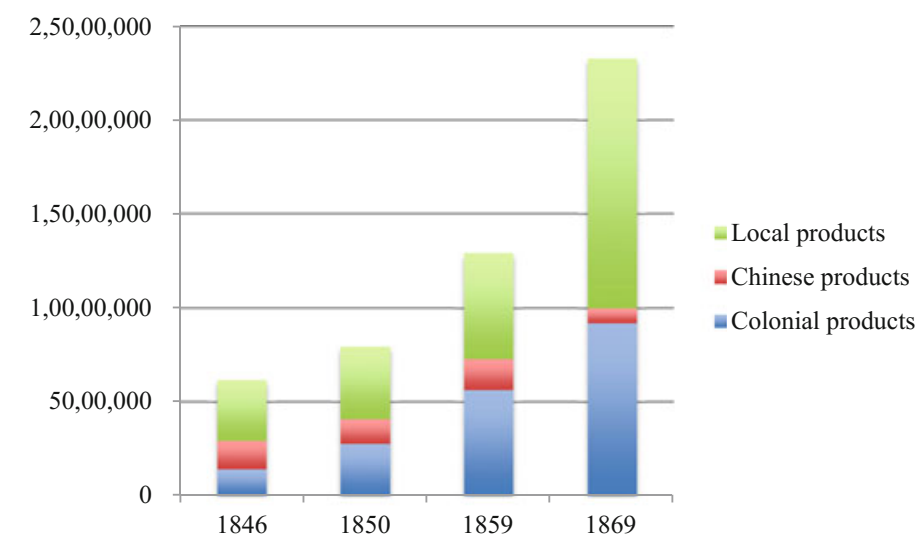

Fig. 4.1 Export from the Dutch ports in the Outer Islands, 1846-69 (Dutch guilders). Sources Direkteur der Middelen en Domeinen 1851-70

and gambir for leather tanning). Therefore, the export of these products is included in the "Colonial products" in 1869 of Fig. 4.1.

Local products and Chinese products in Fig. 4.1 were mostly exported to China, and these consists of various kinds of items such as tin, pepper, birds' nests, sea cucumber, and rattan, that is, typical items of mass consumption in China in the China-oriented trade. This figure thus clearly indicates that the China-oriented trade was growing from 1846 to 1869 as almost steadily as the export of colonial products, the great majority of which in this period was coffee from West Sumatra and North Sulawesi. In fact the export of colonial products skyrocketed after the 1870 s, when the Dutch colonial government allowed private companies for more freedom in trade and production, and as a result the production of tobacco, sugar, and other products rapidly expanded in East Sumatra and some other places. Unfortunately it is impossible to analyze the trade trend in this phase in the same manner because of the significant changes in the format of statistics after 1870. It is very clear, however, that the China-oriented trade was still growing in the Outer Islands from 1846 to 1869, the period when the Singapore-centered regional trade was rapidly expanding and thus the colonial trade structure was being established (Ota 2013).

Figure 4.2 shows the trend of imports from various regions to the Dutch Outer Islands ports from 1846 to 1869 , based on the same sources used in Fig. 4.1. This figure indicates that an increase of European products, among them textiles, was most remarkable. Most of them were British cotton textiles, the import of which expanded after the Dutch authorities accepted the British request to lower their discriminative customs against British products in Dutch East Indies in the 1820s (Kobayashi 2013). Indian textiles occupied about $10.8 \%$ of the total import in 1846, but in the following years the trade considerably shrunk. The "household items" was explained in the original sources to have come from China, Manila, and Siam, but considering the trade volume with these regions, most of them must have come from China. British cotton 


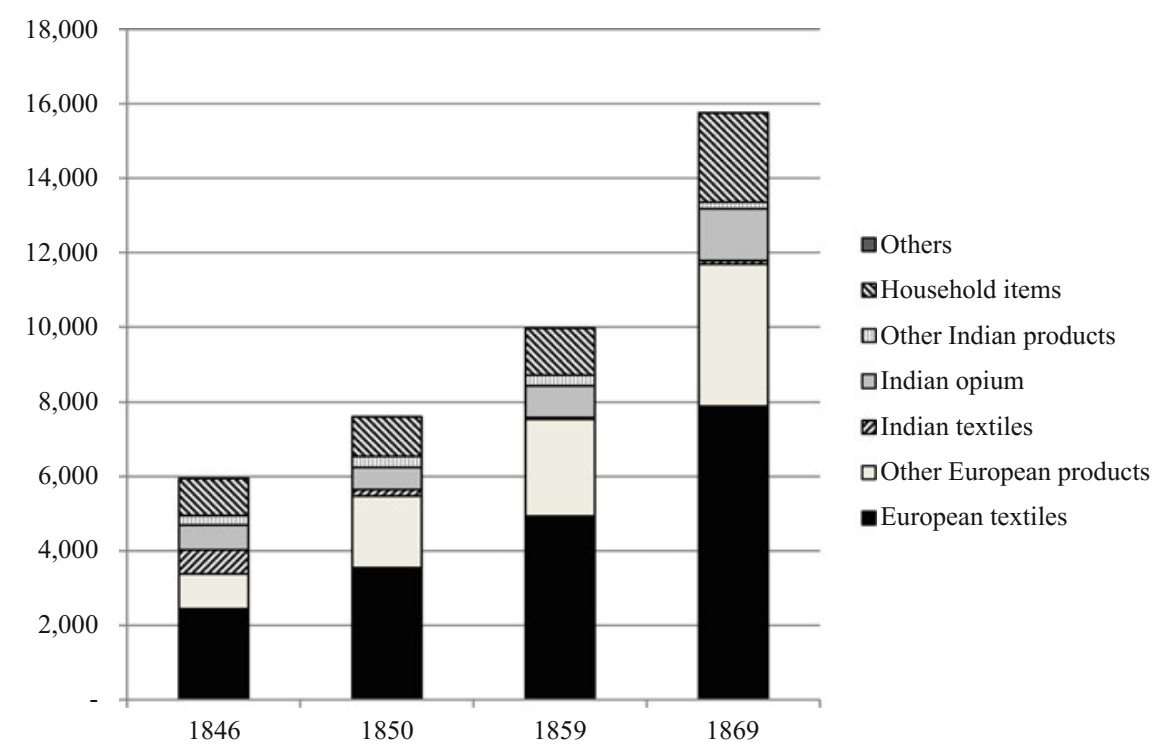

Fig. 4.2 Imports into the Dutch Outer-Islands Ports, 1846-1869 (1,000 Dutch guilders). Sources Direkteur der Middelen en Domeinen 1851-70

textiles were distributed almost exclusively via Singapore, while other items came mostly either via Singapore or Javanese ports such as Batavia and Surabaya, and the small remaining part via Manila and other ports (Ota 2013). These observations suggest that in imports, the Singapore-centered trade pattern increasingly incorporated the Outer Islands. Chinese and Indian imports no longer played a crucial role, while British cotton textiles seem to have taken over the demand for imported textiles.

The available statistical sources inform us, under the heading of "export destinations," of only the first ports to which items were sent, even though large parts of them were re-exported to other places. Nevertheless the "export destinations" deserve analysis, as a first step, in order to grasp the pattern of regional trade. Figure 4.3 indicates that the export to Java and Madura was steadily growing from 1846 to 1869 . This is a result of the Dutch efforts to create Java-centered trade networks, redirecting the Singapore-centered trade to ports in Java, by offering favorable conditions such as tax reductions. Many traders, however, still preferred Singapore, where they were able to find items demanded in the Outer Islands, such as British cotton textiles, more easily. The result was almost the same pace of expansion of the trade to Straits Settlements (mostly Singapore) and the trade to Java. Second, the figure indicates the increasing importance of the long-distance trade. The largest increase took place in the export to Europe and the U.S. This is a result of the Dutch attempts to increase the direct export of coffee to the Netherlands first from West Sumatra, and then from North Sulawesi, in order to reduce the dependence on Singapore. In terms of export destinations, therefore, the increasing importance of the colonial setting is obvious. The Singapore was a powerful colonial port equipped with modern facilities such as 


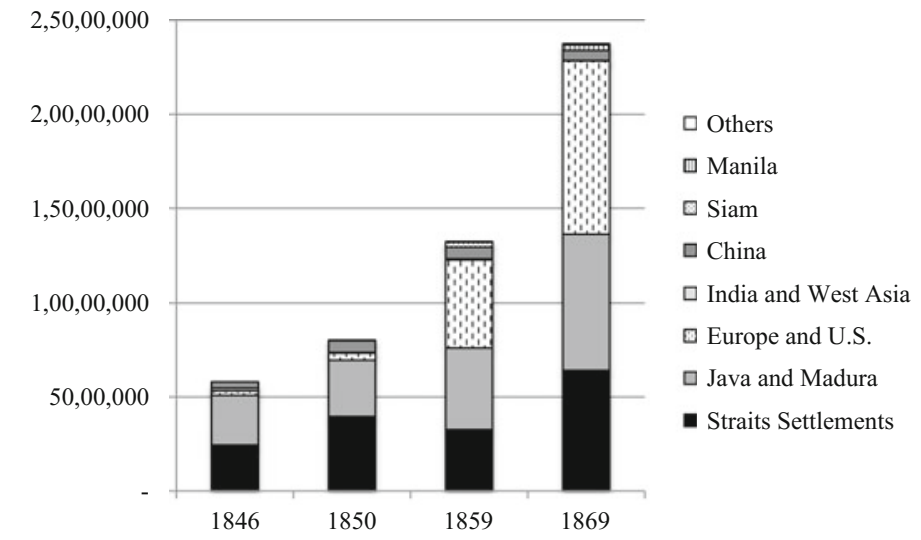

Fig. 4.3 Destinations of items exported from the Dutch ports in the Outer Island, 1846-69 (Dutch guilders). Sources Direkteur der Middelen en Domeinen 1851-70

large-scale harbors and advanced legal and financial systems, and so were Dutch ports like Batavia and Surabaya to a lesser degree. Large volumes of natural products were still exported to China, but traders now preferred these colonial ports as their transit ports. The Dutch effort to establish a Java-centered network was more successful than had been assumed so far, ${ }^{6}$ while Singapore also increasingly attracted Outer-Islands exports. Trade hubs significantly shifted from dispersed numerous small ports in the Age of the China-oriented trade to a small number of modern ports in the colonial period.

The traders who participated in this changing trade pattern were a mixture of new and old actors. After the 1830s Chinese traders based in Singapore became influential in the trade between Singapore and various ports in the Outer Islands. Among them those who obtained Western sailing ships became important players (Wong 1960: 74-84; Reid 1993b: 28-29). In other words, newly emerged merchants in Singapore took a leading position, making use of new, if not the newest, technology. However, the Bugis who commanded pinisi, traditional sailing ships in East Indonesia, continued to play an important role especially between Surabaya and the eastern part of the Archipelago. These Chinese and Bugis traders carried products bound for the China and Southeast Asian markets to Singapore and major ports in Java, and in return redistributed various imported items, among them British cotton textiles, from these ports to various places in the Archipelago (Ota 2013; Kobayashi 2013).

What have been discussed in this section indicates that the China-oriented trade maintained its importance in Southeast Asian trade in the mid-nineteenth century, but it was conducted in the changing settings. Bugis traders continued to play an

\footnotetext{
${ }^{6}$ For example, Thomas J. Lindblad discusses that Dutch efforts to create a Java-centered trade network was not successful because Singapore continued to pull large parts of the exports from the Outer Islands, on the basis of the observations of colonial officials, but not of statistical sources (Lindblad 2002).
} 
important role in the collection of early-modern types of Southeast Asian products, while they and the newly participated Singapore-based Chinese traders brought the products not to numerous small ports used in the previous decades but to Singapore and the major ports in Java. These traders distributed imported items to the producing regions of China-bound natural products, but the imported items were now not Indian textiles but mostly European items. Asian traders preferred Singapore, which now integrated the role of numerous small ports in nearby waters in the previous decades, while the Dutch authorities attempted to attract local traders to the major ports in Java. Under the new setting of the colonial economic structure, the China-oriented trade was maintained with some partial transformations. Some elements that facilitated the Chine-oriented trade, such as Chinese and Bugis traders and their networks, also buttressed the colonial trade structure.

Among the Singapore-based Chinese traders, some expanded the scale of their business and started to accumulate their capital, mainly through intermediation between British and Southeast Asian or Chinese traders (Kobayashi 2013). Some of them further expanded their wealth in the later decades. In this sense the continuing China-oriented trade provided the basis of the accumulation of Chinese capital in the high colonial era, although it did not work well among Bugis and other Southeast Asian entrepreneurs.

Why did the China-oriented trade continue to the colonial period? First, there was still strong Chinese demand on Southeast Asian natural products. Second, local people in the producing regions of China-bound items were market-oriented enough to respond to the demand on their products. Third, while these people had an increasing purchasing power through their export of natural products, they seem to have relied necessities such as textiles on import. The colonial trade structure focused on the producing regions of export products for the Western market, while the Chinaoriented trade continued to deal in the imports and exports in many other regions, where people had been well market-oriented and trade-dependent.

\subsection{Conclusions}

As mentioned at the beginning of this chapter, it is an interesting feature that Southeast Asia experienced brisk local and regional trade in the precolonial period. Although the patterns of the precolonial trade were constantly changing, the general trend in the early-modern era was the shift from state initiative to non-state initiative in the promotion of the trade. During the Age of Commerce (c. 1450-1680) states played a prominent role in the militarily protection of trade ports, creation of cosmopolitan port cities, promulgation of rules and regulations of commerce, and control of the production and trade of important export products. The state control of production and trade was possible and effective because they mainly dealt in small-volume, high-value items such as precious spices and wood, which were produced in very limited areas and traded in a small number of ports. After the Age of Commerce, the China-oriented trade started to develop in the mid-eighteenth century. During the 
Age of China-oriented trade (c. 1750-1870), non-state commercial-military groups, often called pirates, played an important role in local and regional trade. Their heavily armed fleets were effective to collect marine and forest products demanded in China, in remote areas under weak state control. State control of production was no longer effective on these products, which could be collected in numerous coasts and forests. Many states attempted to maintain a good relationship with commercial-military groups, providing privileges in return for their commercial and military support.

The colonial trade pattern rapidly made a shape in the 1820 s after the British establishment of Singapore (1819). The colonial trade patterns expanded to entire Southeast Asia, especially intensively to its insular part, buttressed by the modern port, legal, and financial facilities in Singapore, and the import of British cotton textiles, which now took over the demand for Indian textiles. However, the Singaporecentered trade pattern neither completely brought an end to the China-oriented trade nor imposed totally new systems. On the contrary, old systems survived in the new settings. It was existing Bugis trade network that distributed British cotton textiles to ports in the Outer Islands. People in these ports had purchasing power to consume imported items because of their export of China-bound products. The Singaporecentered trade patterns expanded, on the basis of the elements that had developed in the early-modern trade structure.

What sort of significance did the early-modern trade have in the economic history of Southeast Asia? First, large parts of Southeast Asia came to heavily depend on trade to obtain food and other necessities. In other words, they became trade-dependent and had to continue trade for their survival. Second, it made possible the gradual transition to modern trade patterns. The colonial trade pattern relatively smoothly penetrated the local society because it was able to make use of the existing trade structure. Third, during the Age of the China-oriented trade, the production/collection areas of major export items expanded to much wider areas in coastal and mountain areas. As a result, much larger areas of people were involved in commercial activities and they became more market-oriented. Commercial-military groups, who connected the producing areas to the transit ports were relatively independent from the states. As a result, when independent states fell one by one under the colonial rule, their network and commercial activities continued, because they chose alternative ports, either independent or colonial. The China-oriented trade was maintained, now making use of modern elements, such as British manufactured products, modern port facilities in colonial ports, and shipbuilding technology. In this manner, the colonial trade developed, by combining itself with the China-oriented trade, not by taking over the latter.

Considering the continuity from the early-modern to modern eras as discussed above, it is possible to argue that the basis of the Anglo-Dutch international order, in which free trade was pursued in colonial Asia (Sugihara 1996), had been created in the early-modern era. Southeast Asian and Chinese traders and producers preferred free trade, in which state intervention was minimum, to an increasing degree, from the Age of Commerce to the Age of the China-oriented trade. It was the tradition of trade-dependent and market-oriented society that made possible the pursuit of free trade without state protection. 
The pursuit of free trade without state protection and legal framework to guarantee private properties also had its drawbacks. Until the colonial regimes brought legal framework to protect their business and properties, there was virtually no capital accumulation in insular Southeast Asia. States did not have enough experiences to promote commerce and trade through appropriate economic policy.

All these experiences and lack of experiences seem to have created the basis of Southeast Asian economy in the following periods until today. Society is tradedependent and market-oriented, while capital accumulation was extremely limited until recent decades, except for those who were strongly connected to the state and outside capital. States were not really capable to conduct appropriate economic policy, and legal framework did not develop well to guarantee the safe and amicable business environment. Because of this basis the regional division of labor (between export item-producing regions and food-producing regions) developed in the high colonial period, while capital-intensive industrialization did not fully develop in the period after independence in most parts of Southeast Asia until quite recent decades, although micro-scale commerce has relatively well developed. The lack of capital accumulation and effective state economic policy were bottleneck of the economic development in many Southeast Asian states for several decades after independence. In recent years, however, while manufacturing industry stands still, micro-scale service industry based on internet facilities without large capital is mushrooming in several states. Southeast Asia seems to follow its historical path of economic development, and its market-oriented tendency embedded in society, without heavily depending on state protection, will perhaps have advantage in non-capital-intensive industries in the coming years.

\section{References}

Andaya, L. Y. (1995). The Bugis-Makassar diasporas. Journal of the Malaysian Branch of the Royal Asiatic Society, 68(1), 119-138.

Blussé, L. (1999). The Chinese century: The eighteenth century in the China Sea Region. Archipel, $58,107-129$.

Direkteur der Middelen en Domeinen. (1862-1870). Overzigt van den handel en de scheepvaart in de Nederlandsche bezittingen in Oost Indie, buiten Java en Madura, over de jaren ... [Overview of trade and shipping in the Dutch possessions in the East Indies, apart from Java and Madura, for the years ...]. Batavia: Landsdrukkerij.

Kobayashi, A. (2013). The role of Singapore in the growth of intra-Southeast Asian trade, c. 1820s-1852. Southeast Asian Studies, 2(3), 443-474.

Lindblad, J. T. (2002). The outer islands in the 19th century: Contest for the periphery. In H. Dick, V. J. H. Houben, J. T. Lindblad, \& T. K. Wie, The emergence of a national economy: An economic history of Indonesia, 1800-2000 (pp. 82-110). St Leonards: Allen \& Unwin; Leiden: KITLV Press.

Ota, A. (2006). Changes of regime and social dynamics in West Java: Society, state, and the outer world of Banten, 1750-1830. Leiden and Boston: Brill.

Ota, A. (2010). The business of violence: Piracy around Riau, Lingga, and Singapore, 1820-40. In R. J. Antony (Ed.), Elusive pirates, pervasive smugglers: Violence and clandestine trade in the Greater China Seas (pp. 127-141). Hong Kong: Hong Kong University Press. 
Ota, A. (2013). Tropical products out, British cotton in: Trade in the Dutch Outer Islands ports, 1846-69. Southeast Asian Studies, 2(3), 499-526.

Ota, A. (2014). Toward cities, seas, and jungles: Migration in the Malay Archipelago, c. 1750-1850. In J. Lucassen \& L. Lucassen (Eds.), Globalising migration history: The Eurasian experience (16th-21st centuries). (pp. 180-214). Leiden and Boston: Brill.

Pomerantz, K. (2000). The great divergence: China, Europe, and the making of the modern world economy. Princeton: Princeton University Press.

Reid, A. (1993a). Southeast Asia in the age of commerce 1450-1680 Vol 2: Expansion and crisis. New Haven and London: Yale University Press.

Reid, A. (1993b). The unthreatening alternative: Chinese shipping in Southeast Asia 1675-1842. Review of Indonesian and Malaysian Affairs, 27, 13-32.

Reid, A. (1997). Introduction. In A. Reid (Ed.), The last stand of Asian autonomies: Responses to modernity in the diverse states of Southeast Asia and Korea, 1750-1900 (pp. 1-25). Basingstoke and London: Macmillan Press.

Sugihara, K. (1996). Ajia kan boeki no keisei to kozo (The Formation and structure of intra-Asian trade). Kyoto: Minerva Shobo.

Trocki, C. A. (1979). Prince of pirates: The Temenggongs and the development of Johor and Singapore, 1784-1885. Singapore: NUS Press.

Warren, J. F. (1981). The Sulu Zone, 1768-1898: The dynamics of external trade, slavery, and ethnicity in the transformation of a Southeast Asian Maritime State. Singapore: Singapore University Press.

Wong, L. K. (1960). The trade of Singapore, 1819-1869. Journal of the Malayan Branch of the Royal Asiatic Society, 30(4), 1-315.

Open Access This chapter is licensed under the terms of the Creative Commons AttributionNonCommercial-NoDerivatives 4.0 International License (http://creativecommons.org/licenses/bync-nd/4.0/), which permits any noncommercial use, sharing, distribution and reproduction in any medium or format, as long as you give appropriate credit to the original author(s) and the source, provide a link to the Creative Commons licence and indicate if you modified the licensed material. You do not have permission under this licence to share adapted material derived from this chapter or parts of it.

The images or other third party material in this chapter are included in the chapter's Creative Commons licence, unless indicated otherwise in a credit line to the material. If material is not included in the chapter's Creative Commons licence and your intended use is not permitted by statutory regulation or exceeds the permitted use, you will need to obtain permission directly from the copyright holder.

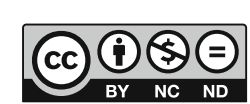

